Леонтович С. П., к.е.н., (ORCID: 0000-0002-0393-1869)

Центр воєнно-стратегічних досліджень Національного університету оборони України імені Івана

Черняховського, Київ

\title{
Обгрунтування підходів до порядку інформатизації процесів організації оборонного планування на основі спроможностей
}

\author{
Резюме. У статті наведено підходи до інформатизації процесів оборонного планування на основі \\ спроможностей за видами планування. \\ Ключові слова: планування; спроможності; інформатизація процесів; оборонні ресурси.
}

Постановка проблеми. Ведення Збройними Силами України бойових дій на сході та півдні України поставили завдання щодо набуття та підтримання силами оборони необхідного рівня бойової готовності і здатності до виконання завдань оборони держави (оборонних спроможностей), підвищення рівня оперативної сумісності Збройних Сил та інших військових формувань України з підрозділами збройних сил державчленів НАТО та ЄС до виконання спільних завдань в міжнародних операціях із підтримання миру і безпеки [1].

Проблемами функціонування сил оборони в умовах наявних i потенційних загроз $є$ недосконалість процедур оборонного планування, їх недостатня узгодженість 3 бюджетним процесом, недосконалість механізмів програмного управління оборонними ресурсами; проблем функціонування сил оборони [2].

Таким чином, організація інформатизаиії процесів планування на основі спроможностей (ПОС) $є$ одним 3 кроків підвищення рівня боєготовності Збройних Сил, досягнення їх сумісності 3 підрозділами країн-членів НАТО та обумовлює актуальність і наукову значущість статті.

Ступінь розробленості проблеми. Останніми роками у Міністерстві оборони України триває робота 3 розроблення та впровадження підходів до планування на основі спроможностей (ПОС) завдяки впровадженню систем оцінювання спроможностей.

Провідними у формуванні та впровадженні ПОС $\epsilon$ праці I. С. Руснака, P. I. Тимошенка, М. М. Дєнєжкіна, А. М. Сиротенка та інших [2-7]. Важливими в інформатизації ПОС у Збройних Силах $\epsilon$ науково-дослідні установи Міністерства оборони України та Збройних Сил України.

Проте у зазначених наукових роботах не надано рекомендацій 3 порядку інформатизації процесів ПОС.

Визначення завдань i напрямів інформатизації процесів оборонного планування на основі спроможностей за строками (видами) може зняти частину проблемних питань і зробити процес втілення ПОС швидшим.

Мета статті - визначення основних завдань та напрямів інформатизації процесів організації ПОС.

Виклад основного матеріалу. У сучасних умовах розвиток сектору безпеки $\mathrm{i}$ оборони України потребує удосконалення системи планування та іiі удосконалення із застосуванням принципів і стандартів ЄС та НАТО, використанням сучасних європейських та євроатлантичних підходів, запровадження системи планування на основі спроможностей, узгоджуючи цей процес із програмно-цільовим та іншими сучасними методами планування фінансових і матеріально-технічних ресурсів із подальшим розробленням концепції розвитку спільних спроможностей [3].

Упровадження процесу оборонного планування відповідно до євроатлантичних принципів і підходів передбачає у Міністерстві оборони удосконалення системи оборонного планування, перехід на програмну систему оборонного та бюджетного планування, формування щорічного оборонного бюджету та забезпечення надійного бюджетного прогнозування на наступні два-три роки, яке включатиме реалістичні та доступні (у ціновому розумінні) положення, розкриті у достатній деталізації для підвищення відповідальності та ефективності (фінансової) управління процесами планування та бюджетування [2].

Одним 3 напрямів розвитку процесів планування $\epsilon$ розроблення сучасних систем інформатизації, використання інформаційнокомунікаційних технологій, поступове наближення процесів ПОС України до показників і стандартів НАТО [3]. 
Метою інформатизації процесів організації оборонного ПОС $є$ визначення стратегії розв'язання проблем забезпечення інформаційних потреб і створення систем інформаційної підтримки.

Інформатизація ПОС спрямована на вирішення завдань:

інформатизації процесів формування правових, організаційних, науково-технічних, фінансових, економічних, методичних та інших пріоритетів і напрямків розвитку;

упровадження сучасних інформаційних технологій у відповідних процесах;

формування бази інформаційних ресурсів за кожним функціональним напрямом;

створення відповідної мережі інформаційного забезпечення та систем інформаційно-аналітичної підтримки ПОС на основі інформаційних технологій;

під'єднання та використання інформаційного простору оборонних відомостей країн НАТО;

використання стандартів, норм і правил інформатизації;

державної підтримки та фінансування пріоритетних напрямів.

Інформатизація

(автоматизація) процесів ПОС спрямована на оцінювання $\mathrm{i}$ визначення вимог до основних етапів оборонного планування, їх поєднання 3 функиіональними групами (інтегрованими категоріями) спроможностей Збройних Сил.

Оцінювання та визначення вимог до основних етапів планування включають:

уточнення засад та оцінювання середовища безпеки;

визначення вимог до спроможностей застосування Збройних Сил i формування переліку спроможностей;

розподіл завдань і визначення

спроможностей;

імплементація і виконання завдань щодо

розвитку спроможностей;

оцінювання ступеня досягнення

спроможностей [5].

Функціональні групи (інтегровані категорії) спроможностей Збройних Сил включають:

забезпечення готовності Збройних Сил діяти відповідно до прогнозованих сценаріїв (FORCE SUPPORT); співробітництво у сфері безпеки i оборони (PREPARE); розгортання та мобільність військ (PROJECT); застосування (ENGAGE); забезпечення (SUSTAIN); керівництво та управління (CONSULT, COMMAND \& CONTROL);

захист і живучість (PROTECT); розвідка (INFORM); воєнно-політичне управління ресурсами (CORPORATE MANAGEMENT \& SUPPORT) [4].

Пріоритетними напрямами проведення інформатизації короткострокового, середньострокового та довгострокового ПОС $\epsilon$ створення програмних інструментів автоматизованої підтримки зазначених процесів, здійснення аналізу i визначення інформації з урахуванням базових компонентів (складових) спроможностей (DOTMLPFI).

Пропонується варіант першочергової інформатизації основних процесів під час прийняття рішень і поєднання 3 базовими компонентами, інформаційна підтримка (автоматизація) яких надасть максимальний ефект:

1) Під час довгострокового ПОС щодо коригування, обробки та аналізу інформації стосовно:

потенційних військових загроз;

можливості національної економіки у розрізі загальнодержавних цільових програм діючої нормативно-правової бази з питань ПОС (D - доктринальна база);

форм і способів застосування Збройних Сил (О - організація);

матеріальних, фінансових i людських ресурсів ( $\mathbf{T}$ - підготовка, $\mathbf{L}$ - якість управління та освіта, $\quad \mathbf{P}$ - персонал, $\mathbf{F}$ - військова інфраструктура);

результатів проведення оборонного огляду та викладених рекомендацій Стратегічному оборонному бюлетені України (I - сумісність).

2) Під час середньострокового ПОС щодо коригування, обробки та аналізу інформації стосовно:

опрацювання положень Стратегічного оборонного бюлетеня України (D доктринальна база);

фінансування сектору оборони (М ресурсне забезпечення);

результатів огляду спроможностей (O організація);

стану виконання державних цільових програм;

інформатизації процесів отримання інформації для опрацювання комплексних документів 3 розвитку спроможностей та визначення кроків досягнення оперативних 
цілей, необхідних спроможностей через зміну кількісних i якісних характеристик організаційної структури Збройних Сил (T підготовка, $\mathbf{L}$ - якість управління та освіта, $\mathbf{P}$ - персонал, $\mathbf{F}$ - військова інфраструктура, I - сумісність).

Інформатизація

опрацювання комплексних документів включає розроблення програмного інструменту для аналізу:

ризиків та загроз воєнній безпеки;

способів та масштабів застосування

Збройних Сил за сценаріями;

визначення параметрів перспективної

організаційної структури Збройних Сил та

забезпечення iї потреб;

обсягів прогнозного ресурсного

забезпечення Збройних Сил;

етапів досягнення спроможностей за

всіма складовими компонентами.

3) Під час короткострокового ПОС щодо коригування, обробки та аналізу інформації стосовно:

удосконалення процесів обробки інформації 3 розроблення військовополітичних вказівок на наступний та два послідуючих роки (D - доктринальна база, $\mathbf{T}$ підготовка, I-сумісність);

визначення попередніх показників проекту держбюджету на наступний рік та два послідуючих роки (М - ресурсне забезпечення, $\mathbf{L}$ - якість управління та освіта, $\mathbf{P}$ - персонал, $\mathbf{F}$ - військова інфраструктура);

відпрацювання пропозицій до проекту основних показників у державне оборонне замовлення (M - ресурсне забезпечення, $\mathbf{L}$ якість управління та освіта, $\mathbf{P}$ - персонал, $\mathbf{F}$ військова інфраструктура);

формування зведеного кошторису за

міністерство;

визначення складових в орієнтовний

план і план утримання та розвитку Збройних Сил (О - організація).

Висновки. Таким чином, запропоновано підходи до порядку інформатизації процесів організації ПОС, зокрема, визначені пріоритетні напрями проведення інформатизації короткострокового, середньострокового та довгострокового ПОС, здійснення аналізу і визначення інформації 3 урахуванням базових компонентів (складових) спроможностей (DOTMLPFI).

Зазначені підходи інформатизації дадуть змогу надалі удосконалити процеси ПОС, в нинішніх умовах 3 урахуванням наявних (можливих) ресурсів, та здійснити їх поєднання (взаємозв'язок) із відповідними функціональними групами спроможностей Збройних Сил для їх динамічного розвитку.

Однією 3 головних умов динамічного розвитку та впровадження інформатизації ПОС $\epsilon$ врахування вимог до спроможностей та адаптація перспективної системи оборонного планування Збройних Сил України до аналогічних систем країн-членів НАТО.

Надалі інформатизація ПОС має бути сконцентрована на інтегруванні процесів інформатизації планування до євроатлантичних принципів та підходів, 3 урахуванням досвіду країн-членів Альянсу. Розроблений підхід доцільно використати під час подальших досліджень проблем щодо удосконалення методів оборонного планування в Збройних Силах України.

\section{СПИСОК ВИКОРИСТАНОЇ ЛІТЕРАТУРИ}

1. План дій щодо впровадження оборонної реформи у 2016 - 2020 роках (ДОРОЖНЯ КАРТА ОБОРОННОЇ РЕФОРМИ), [Електронний ресурс].

- Режим доступу: www.mil.gov.ua/content/tenders/ Plan_2208.pdf.

2. Стратегічний оборонний бюлетень України, [Електронний ресурс]. - Режим доступу: zakon.rada.gov.ua/go/n0006525-16.

3. Концепція розвитку сектору безпеки і оборони України, [Електронний ресурс]. - Режим доступу: zakon.rada.gov.ua/go/92/2016

4. Рекомендації з оборонного планування на основі спроможностей в Міністерстві оборони України та Збройних Силах України, [Електронний ресурс]. Режимдоступу:www.mil.gov.ua/...

/Recommendationson_CBP_120617.pdf.

5. Денежкін М. М. Особливості оборонного планування у державах-членах НАТО, на основі спроможностей

/М. М. Денежкин, А. Д. Наливайко, А. І. Поляєв// Зб. наук. пр. ЦВСД НУОУ, - 2017. - № 2(60). - С 34-37, [Електронний ресурс]. - Режим доступу: journals.uran.ua/index.php/2304-2699/issue /viewFile/7396/2945.

6. Дєнєжкін М. М., Крикун П. М., Р Руснак I. С. Проблеми проведення комплексного огляду сектора безпеки та оборони України: погляди на його організацію та вирішення завдань // Наука і оборона. - 2014. - № 4.

7. Сиротенко А. М., Методика проектування необхідних спроможностей складових інтегрованого потенціалу деескалації загроз на виконавчому рівні / А. М. Сиротенко, В. Ю. Богданович, І. Ю. Свида // 3б. наук. праць ЦНДІ ЗС України. - К., 2017. - № 3 (81). C. 48-56. 
Леонтович С. П., к.е.н.

Центр военно-стратегических исследований Национального университета оборони Украины имени Ивана Черняховского, Киев

Подходы к порядку информатизации процессов организации оборонного планирования на основании возможностей

Резюме. В статье представлены подходы к информатизации процессов оборонного планирования по видам планирования.

Ключевые слова: планирование; возможности; информатизация процессов; оборонные ресурсы.

\section{S. Leontovych, PhD, (Economic)}

Center for Military and Strategic Studies of the National Defence University of Ukraine named after Ivan Cherniakhovskyi, Kyiv

Approaches to the order of informatization of defense planning organization processes based on capabilities presented.

Resume. The approaches to the informatization of defense planning processes by type of planning are

Keywords: planning; capacity; process informatization; defense resources. 